\title{
Sosialisasi Penerapan Sapta Pesona Dalam Perencanaan Dan Pengembangan Destinasi Pariwisata Berkelanjutan Di Lider Desa Sumberarum Kecamatan Songgon Kabupaten Banyuwangi
}

\author{
Kanom $^{1,}$ Randhi Nanang Darmawan², Nurhalimah ${ }^{3}$ \\ ${ }^{1,2,3}$ Politeknik Negeri Banyuwangi \\ Email : kanom@poliwangi.ac.id ${ }^{1}$, randhi@poliwangi.ac.id ${ }^{2}$, nurhalimah@poliwangi.ac.id ${ }^{3}$
}

\begin{abstract}
Lider is one of the hamlets in Sumberarum Village is one of the destinations in Banyuwangi with the main attraction is Lider Waterfall which is the highest waterfall in Banyuwangi, located quite well on its human resources in the field of tourism. Therefore, the implementation team of the Community Service Program is called PKM Tourism Business Management Study $(M B P)$ Banyuwangi State Polytechnic works with partners namely the Tourism Awareness Group (Pokdarwis) Sumberarum Village and Bejong Hamlet residents in the field of socialization of the Implementation of Sustainable Tourism Enchantment in Lider Village Sumberarum Songgon District, Banyuwangi Regency. The results of this PKM activity were positively invited by all members of the community and made partners open to their views on current developments in the world of tourism. In addition, the results of this PKM activity began to take shape with the reopening of access to the attraction of the Stone Table which was moved to become a natural attraction for trekking and adventure.
\end{abstract}

Keywords: Socialization of Sapta Enchantment Application, Planning and Development, Sustainable Tourism Destinations, Community Service.

\begin{abstract}
Abstrak
Lider adalah salah satu dusun di Desa Sumberarum merupakan salah satu destinasi pariwisata di Banyuwangi dengan daya tarik utama adalah Air Terjun Lider yang merupkan air terjun tertinggi di Banyuwangi, lokasinya lumayan terpencil baik dari akses maupun fasilitas umum yang masih minim dengan jumlah penduduk yang relatif rendah sumber daya manusianya terutama pada bidang pariwisata. Oleh sebab itu tim pelaksana Pengabdian Kepada Masyarakat (PKM) Program Studi Manajemen Bisnis Pariwisata (MBP) Politeknik Negeri Banyuwangi bekerja sama dengan mitra yaitu Kelompok Sadar Wisata (Pokdarwis) Desa Sumberarum dan warga Dusun Bejong dalam bentuk Sosialisasi Penerapan Sapta Pesona Dalam Perencanaan Dan Pengembangan Destinasi Pariwisata Berkelanjutan Di Lider Desa Sumberarum Kecamatan Songgon Kabupaten Banyuwangi. Hasil dari kegiatan PKM ini disambut positif oleh seluruh warga masyarakat dan membuat mitra terbuka pandangan tentang perkembangan dunia pariwisata saat ini. Selain itu hasil kegiatan PKM ini mulai berwujud dengan pembukaan kembali akses rute menuju daya tarik Batu Meja yang berpotensi menjadi daya tarik wisata alam trekking dan petualangan.
\end{abstract}

Kata Kunci: Sosialisasi Penerapan Sapta Pesona, Perencanaan dan Pengembangan, Destinasi Pariwisata Berkelanjutan, Pengabdian Kepada Masyarakat. 


\section{Pendahuluan}

Lider merupakan salah satu destinasi pariwisata di Banyuwangi dengan pesona air terjun sebagai daya tarik utamanya serta beberapa daya tarik pendukung lainya.

Nama Lider, sepintas seluruh orang di Banyuwangi bahkan di Indonesia akan tahu bahwa nama tersebut adalah nama sebuah air terjun yang terkenal, dan merupakan tertinggi di Banyuwangi, akan tetapi sedikit orang mengetahui tentang Dusun Lider, suatu dusun terpencil beberapa kilometer sebelum air terjun Lider. Tidak heran mengenai hal tersebut, karena hampir seluruh situs atau website, media sosial pada zaman sekarang yang membahasa Air Terjun Lider menganggap air terjun tersebut ada di Desa Sragi, dan rute untuk sampai kesanapun melalui Dusun Bejong bukan Dusun Lider. Padahal Dusun Lider sendiri memiliki beberapa daya Tarik wisata yang punya potensi besar untuk dikembangkan dan tidak kalah dengan Dusun Bejong tetangganya tersebut, diantaranya dataran tinggi Batu Meja, Pembangkit Listrik Hidro Mikro, dan Air Terjun Lider.

Mitra dalam kegiatan PKM ini adalah kelompok sadar wisata (Pokdarwis) Desa Sumberarum Kecamatan Songgon, yang masih belum menyentuh daya tarik wisata yang ada di Dusun Lider, info terakurat dari kepala Dusun Lider, pokdarwis Desa Sumberarum sudah pernah mengembangkan daya tarik wisata yang ada di Dusun Lider akan tetapi tidak berkembang dan hanya berhenti karena seiring dengan kebijakan kepala Desa Sumberarum yang baru (Sutiyono, 2019).

Permasalahan yang muncul dikalangan masyarakat muncul dari faktor rendahnya SDM masyarakat sekitar tentang potensi daya tarik wisata yang pada dasarnya dapat meningkatkan ekonomi warga sekitar, sehingga tim pelaksana PKM dari Politeknik Negeri Banyuwangi mengadakan sosialisasi Sapta Pesona Pariwisata dan bekerja sama dengan
Kelompok Sadar Wisata Desa

Sumberarum. Dusun Lider seperti dianaktirikan oleh Desa Sumberarum mengingat pemerintah desa lebih mengutamakan destinasi Air Terjun Telunjuk Raung yang beberapa tahun ini menjadi trending topic di Banyuwangi dan juga Villa Bejong yang menjadi spot foto yang instagramable.

Dengan beberapa permasalahan tersebut tim pelaksana PKM dengan Pokdarwis menyatukan visi serta mencoba mengeksplorasi daya tarik yang punya potensi dan memberikan wawasan kepada masyarakat di dusun Lider, agar dapat terciptanya kegiatan kepariwisataan serta terwujudnya pariwisata yang berkelanjutan (Sustainable Tourism).

Penerapan Sapta Pesona merupakan salah satu langkah awal dalam menciptakan suasana destinasi pariwisata yang ramah lingkungan guna mewujudkan destinasi pariwisata berkelanjutan. Dalam rangka penerapan Sapta Pesona idealnya masyarakat dilibatkan secara aktif dalam kegiatan kepariwisataan di Lider dan sekitarnya.

Sapta Pesona merupakan idealnya diterapkan dan diwujudkan dalam rangka menarik minat wisatawan berkunjung ke suatu destinasi pariwisata seperti halnya di Lider, Banyuwangi. Manfaat dari penerapan Sapta Pesona Wisata dalam peningkatan mutu atau kualitas kepariwisataan baik daya tarik wisata ataupun komponen pendukung lainnya seperti di Kecamatan Songgon khususnya Dusun Lider yang merupakan modal dasar bagi pengembangan pariwisata (Rahim, 2012).

Dalam pengembangan destinasi pariwisata yang menitikberatkan pada pembangunan pariwisata berkelanjutan idealnya memperhatikan beberapa aspek keberlanjutan seperti; berkelanjutan secara lingkungan, berkelanjutan secara ekonomi dan berkelanjutan dalam aspek sosial dan budaya masyarakat lokal (Kanom, 2015). Adapun penekanan utama dari konsep pembangunan pariwisata yang berkelan- 
jutan adalah pengelola, stakehoder, pemerintah, pelaku pariwisata, dan masyarakat dituntut untuk mampu menjaga dan mempertahankan kebersihan dan kelestariannya. Penerapan Sapta Pesona adalah jabaran konsep Sadar Wisata yang terkait dengan dukungan dan peran masyarakat sebagai tuan rumah dalam upaya untuk menciptakan lingkungan lestari dan suasana yang kondusif yang mampu mendorong tumbuh dan berkembangnya industri pariwisata, melalui perwujudan unsur aman, tertib, bersih, sejuk, indah, ramah dan unsur kenangan (Sulistyani, 2018)

Guna menyelaraskan Sapta Pesona dengan potensi daya tarik di Dusun Lider, tim PKM melakukan observasi dan eksplorasi daya tarik wisata yang potensial untuk dikembangkan dalam mendukung Lider sebagai destinasi pariwisata yang berkelanjutan beserta sosialisasi dengan Kelompok Sadar Wisata (Pokdarwis) dan warga masyarakat Dusun Lider dengan harapan dapat terciptanya pariwisata yang berkelanjutan dan berdaya saing, serta warga masyarakat Dusun Lider dapat mendapatkan manfaat serta keutungan dari multiflier effect dari kegiatan dan perkembangan pariwisata yang akan dikelola dengan tepat dan efektif (Kanom, 2015).

Hasil kegiatan PKM ini nantinya berupa daya tarik wisata yang dibuka untuk umum dan dapat berkelanjutan sehingga menjadi daya tarik wisata baru di Banyuwangi dengan terwujudnya masyarakat Dusun Lider yang lebih aktif dalam kegiatan kepariwisataan.

\section{Pelaksanaan Dan Metode}

Metode yang dilakukan dalam kegiatan PKM ini adalah eksplorasi dan sosialisasi. Eksplorasi adalah Eksplorasi, disebut juga penjelajahan atau pencarian, adalah tindakan mencari atau melakukan penjelajahan dengan tujuan menemukan sesuatu. Dalam konteks riset ilmiah, eksplorasi adalah salah satu dari tiga bentuk tujuan riset, sedangkan tujuan lainnya ialah penggambaran (deskripsi) dan penjelasan (eksplanasi). Dalam hal ini, eksplorasi destinasi adalah usaha untuk menjelajahi dan membuka kembali jalan untuk pengembangan destinasi baru yang harapannya menjadi pariwisata yang berkelanjutan.

Untuk mencapai harapan tersebut eksplorasi juga dilandasi dengan sosialisasi dasar-dasar ilmu Pariwisata yang tertuang dalam Sapta Pesona. Adapun tahapan proses kegiatan PKM adalah sebagai berikut:

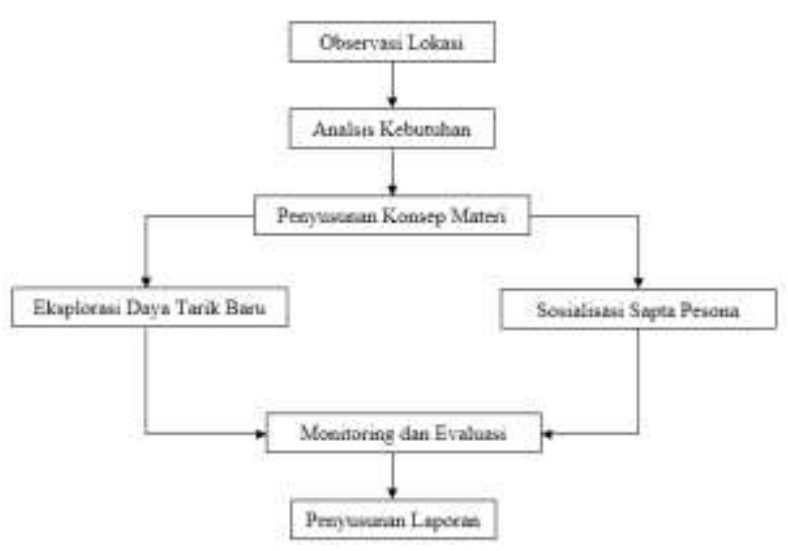

Gambar 1. Skema langkah-langkah kegiatan PKM

\section{Hasil dan Pembahasan}

Tim pelaksana PKM yang didampingi beberapa mahasiswa menggunakan metode pendekatan dengan meningkatkan human touch sebagai bukti bahwa kearifan lokal masih dijunjung tinggi di Dusun Lider, terlihat dengan senyuman wajah warga yang mengikuti kegiatan PKM, dan secara otomatis konsumsi muncul jadi hidangan dalam kegiatan PKM sehingga kehangatan antara tim pelaksana, mahasiswa, dan warga sangat erat dan tiada jarak. Penyampaian materi saat sosialisasi tidak begitu formal dengan menggunakan Bahasa yang mudah dipahami warga, dan proses diskusi berjalan cukup positif dengan antusias warga dalam bertanya dan menyampaikan pendapat. 
Secara garis besar masyarakat Dusun Lider masih belum memahami dunia pariwisata yang telah berkembang seperti saat ini dan manfaat yang ada dari pariwisata tersebut masih belum dirasakan oleh warga, jadi saat beberapa warga yang punya ide - ide kreatif untuk melakukan pengembangan wisata masih terbentur oleh kekompakan warga dan bahkan mayoritas warga menganggap kegiatan pengembangan pariwisata hanya sesuatu yang siasia. Oleh sebab itu tim pelaksana PKM memberikan pandangan dan membuka pola pikir warga seluas- luasnya agar ikut serta dan berperan aktif dalam pengembangan pariwisata, karena efek dari kegiatan tersebut akan dirasakan oleh seluruh warga Dusun Lider.

\section{Proses Sosialisasi Sapta Pesona}

Masyarakat Dusun Lider yang mayoritas adalah pekerja dipekerbunan cengkeh milik perusahaan swasta yang menggunakan tanah yang berstatus HGU (Hak Guna Usaha) menghabiskan waktunya untuk bercengkrama dengan alam, lokasi yang terpencil, akses jalan yang cukup menantang serta sinyal internet yang belum masuk Dusun Lider menjadi permasalahan disana meskipun hal tersebut menjadi nilai tambah untuk keasrian dan kearifan local yang masih terjaga, senyum, sapa, salam, dan hospitality warga Dusun Lider sudah tidak perlu diragukan lagi.

Saat sosialisasi tentang penerapan Sapta Pesona Wisata warga masyarakat cukup antusias dan memberikan respon yang positif, generasi muda Dusun Lider yang kurang begitu mengenyam pendidikan tinggi, yang mayoritas hanya sampai sekolah menengah, menjadi tertarik untuk mengembangkan potensi wisata yang ada di Dusun Lider.

Proses sosialisasi dilakukan dengan metode diskusi disertai tanya jawab dari tim pelaksana, dan memberikan hasil yang positif hal ini dilihat dari ekspresi wajah para warga dan pertanyaan-pertanyaan yang diajukan sebagai wujud bahwa warga
Dusun Lider antusias dalam mengikuti kegiatan PKM.

Warga Masyarakat Dusun Lider yang dimotori oleh Pak Sutiyono sebagai kepala dusun dan Pak Selamet sebagai tokoh masyarakat setempat memberikan apresiasi setinggi-tingginya kepada Program Studi Manajemen Bisnis Pariwisata Politeknik Negeri Banyuwangi yang sudah meluangkan waktu dan mau mendengarkan keluh kesah warga dan juga mau menjadi jembatan penghubung antara warga, pemerintah Desa Serta dengan Dinas Pariwisata Kabupaten Banyuwangi demi terwujudnya destinasi pariwisata yang yang berkelanjutan dan berdaya saing.

Penerapan Sapta Pesona merupakan salah satu langkah tepat dalam meberikan pemahaman bagi masyarakat khususnya warga Dusun Lider, dengan demikian masyarakat dapat mengelola destinasi pariwisata secara aktif dan efektif.

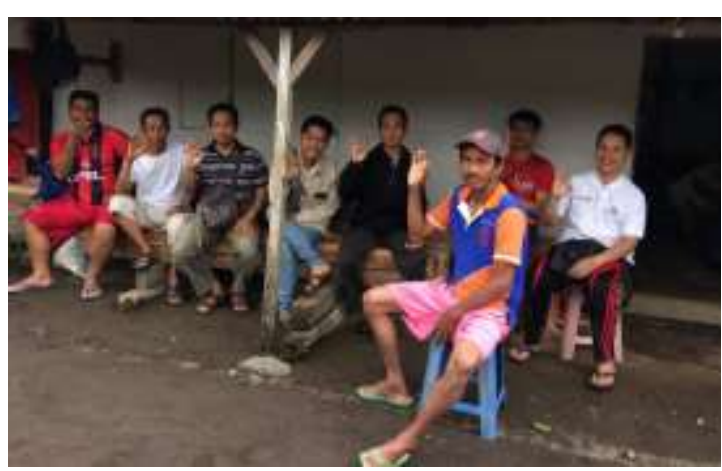

Gambar 2. Diskusi dan sosialisasi Sapta Pesona dengan warga dan pemuda

Pada sesi sosialisasi terkait penerpan Sapata Pesona Pariwisata di Dusun Lider Desa Sumberarum Kecamatan Songgon Kabupaten Banyuwangi terlihat masyarakat sangat antusias dan semangat ketika diskusi terkait dengan potensi dan daya tarik wisata yang ada di wilayahnya. Dengan demikian masyarakat semangat masyarakat ini menjadi salah satu modal besar dalam pengembangan pariwisata yang berkelanjutan dengan tetap menitikberatkan pada keterlibatan masyarakat lokal, baik sebagai pengelola atau pelaku pariwisata. 
Keterlibatan masyarakat dalam kegiatan kepariwisataan merupakan salah satu komponen penting dalam pengembangan pariwisata berkelanjutan. Dengan demikian, masyarakat akan tumbuh rasa memiliki yang tinggi terhadap kegiatan kepariwisataan serta penerapan Sapta Pesona Wisata akan dilaksanakan dengan baik dan menyenangkan.

\section{Eksplorasi Daya Tarik Wisata}

Setelah kegiatan sosialisasi tentang penerapan Sapta Pesona Wisata pada Kelompok Sadar Wisata (Pokdarwis) dan Masyarakat Dusun Lider Desa Sumber Arum Kecamatan Songgon Kabupaten Banyuwangi Jawa Timur, Tim PKM, Mahasiswa berserta Pokdarwis dan masyarakat berlanjut dengan kegiatan eksplorasi potensi dan daya tarik wisata di Lider dan sekitarnya.

Dalam kegiatan eksplorasi tersebut tim PKM sambil berdiskusi terkait dengan potensi dan daya tarik wisata kepada masyarakat dengan menunjukkan yang ideal sebagai daya tarik di Lider dan sekitarnya sesuai dengan landasan hokum maupun teori yang pendukungnya.

Undang-undang

Republik

Indonesia (RI) nomor 10 Tahun 2009 tentang Kepariwisataan, pasal 1 ayat 5 menyebutkan bahwa daya tarik wisata adalah segala sesuatu yang memiliki keunikan, keindahan, dan nilai yang berupa keanekaragaman kekayaan alam, budaya, dan hasil buatan manusia yang menjadi sasaran atau tujuan kunjungan wisatawan (Indonesia, 2009).

Keadaan alam, flora dan fauna, sebagai karunia Tuhan Yang Maha Esa, serta peninggalan purbakala, peninggalan sejarah, seni dan budaya yang dimiliki bangsa Indonesia merupakan sumber daya dan modal pembangunan kepariwisataan untuk peningkatan kemakmuran dan kesejahteraan rakyat sebagaimana terkandung dalam Pancasila dan Pembukaan Undang-undang Dasar (UUD) Negara Republik Indonesia Tahun 1945.
Daya tarik atau atraksi wisata menurut Yoety (2006, 5-6) adalah segala sesuatu yang dapat menarik wisatawan untuk berkunjung pada suatu daerah tujuan wisata seperti; (a) Atraksi Alam: pemandangan, pemandangan laut, pantai, cuaca dan keadaan geografis destinasi tersebut (Natural attraction: landscape, seascape, beaches, climate and other geographical features of the destinations), (b) Atraksi Budaya: sejarah dan folklore, agama, kesenian dan kegiatan khusus, festival (Cultural attraction: history and folklore, religion, art and special events, festivals), (c) Atraksi Sosial: tradisi (cara hidup), populasi penduduk, bahasa, kesempatan berbaur dalam kehidupan sosial (Social attractions: the way of life, the resident populations, languages, opportunities for social encounters), (d) Aktraksi Buatan: gedung bersejarah dan arsitektur modern, monumen, taman, kebun, pelabuhan dan sebagainya (Built attraction: building, historic, and modern architecture, monument, parks, gardens,marina,etc).

Menurut Yoety (2006:55-56) daya tarik wisata dibagi menjadi empat (4) bagian yaitu; (1) Daya Tarik Wisata Alam, yang meliputi pemandangan alam, laut, pantai dan pemandangan alam lainnya., (2) Daya Tarik Wisata dalam bentuk Bangunan, yang meliputi arsitektur bersejarah dan modern, monumen, peninggalan arkeologi, lapangan golf, toko dan tempat-tempat perbelanjaan lainnya., (3) Daya Tarik Wisata Budaya, yang meliputi sejarah, foklor, agama, seni, teater, hiburan, dan museum., dan (4) Daya Tarik Wisata Sosial, yang meliputi cara hidup masyarakat setempat, bahasa, kegiatan sosial masyarakat, fasilitas dan pelayanan masyarakat.

Sebagaimana yang telah dijelaskan secara teoritis Dusun Lider memiliki beberapa daya tarik wisata dan salah satu 
atraksi utama adalah Air Terjun Lider serta pendukungnya, adapun daya tarik wisata di Lider masuk dalam kategori Wisata Alam hingga sangat ideal untuk dikembangkan menjadi destinasi pariwisata berkelanjutan dengan menitikberatkan pada keterlibatan masyarakat lokal.

Dalam pengembangan destinasi pariwisata berjalan menurut siklus evolusi yang terdiri dari tahap pengenalan (introduction), pertumbuhan (growth), pendewasaan (maturity), penurunan (decline) dan atau peremajaan (rejuvenation).

Tujuan utama dari penggunaan model siklus hidup destinasi (destination lifecycle model) adalah sebagai alat untuk memahami evolusi dari produk dan destinasi pariwisata sekaligus untuk mengetahui tahapan pengembangan destinasi pariwisata itu sendiri (Kanom, 2015).

bahwa terdapat enam tahapan pengembangan pariwisata berkelanjuatan yang membawa implikasi serta dampak yang berbeda terhadap pariwisata yaitu (1) Tahap Explorasi, pertumbuhan spontan dan penjajakan (exploration), (2) Tahap Keterlibatan (involment), (3) Tahap Pengembangan dan Pembangunan (development), (4) Tahap Konsolidasi (consolidation), (5) Tahap Ketidaksetabilan (stagnation), dan (6) Tahap Penurunan Kualitas (decline) dan Kelahiran Baru (rejuvenation).

Seiring berjalannya waktu Air Terjun Lider dengan akses yang cukup sulit kurang begitu diminati pengunjung karena Desa Sumberarum memiliki destinasi air terjun lainnya yaitu Air Terjun Telunjuk Raung yang pada awal 2017 sampai sekarang menjadi destinasi wisata pengunjung, baik local bahkan juga dari luar Banyuwangi. Dalam kegiatan PKM ini tim pelaksana bersama pokdarwis dan mahasiswa Manajemen Bisnis Pariwisata bersama-sama mempromosikan kembali Air Terjun Lider melalui berbagai cara, seperti promosi dengan media sosial
Instagram, facebook, WhatsApp, dan website Himpunan Mahasiswa Pariwisata yang ada di kampus Politeknik Negeri Banyuwangi dengan demikian pamor Air Terjun Lider akan meningkat kembali sehingga memberikan dampak positif ke warga Dusun Lider.

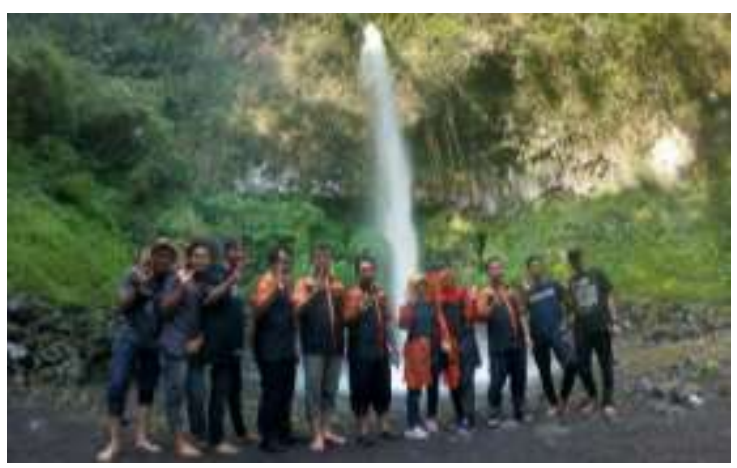

Gambar 3. Sosialisasi dan Eksplorasi Air Terjun Lider dengan Pokdarwis

Struktur geografis Dusun Lider yang terletak di dataran tinggi menyimpan pesona alam yang luar biasa, salah satunya adalah daya Tarik wisata Batu Meja. Namanya unik karena terdapat bongkahan batu besar yang terletak di dataran tinggi dan teratata secara almi tanpa ada campur tangan manusia, lokasi ini sempat dipugar oleh warga akan tetapi karena tidak sejalan dengan pemerintah Desa Sumberarum yang baru maka proses pengembangan Batu Meja mulai terbengkalai dan akses setapak untuk menuju kesana juga mulai menghilang diterpa hujan dalam kurun waktu bebera tahun terakhir.

Dipimpin Pak Selamet tokoh masyarakat Dusun Lider, tim PKM menelusuri ulang jejak-jejak menuju Batu Meja, dengan kondisi jalan yang curam dan melelahkan dengan pendakian yang cukup rumit namun hal tersebut tidak meruntuhkan semangat tim PKM demi pengembangan daya tarik wisata baru. Berikut beberapa gambar pembukaan rute menuju Batu Meja 


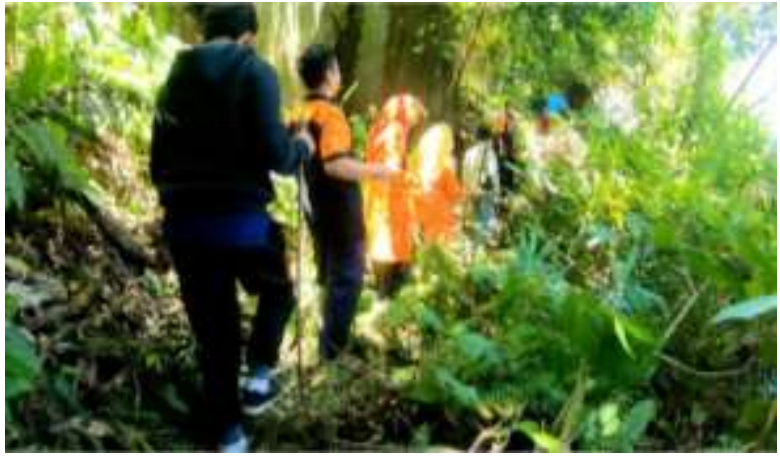

(a)

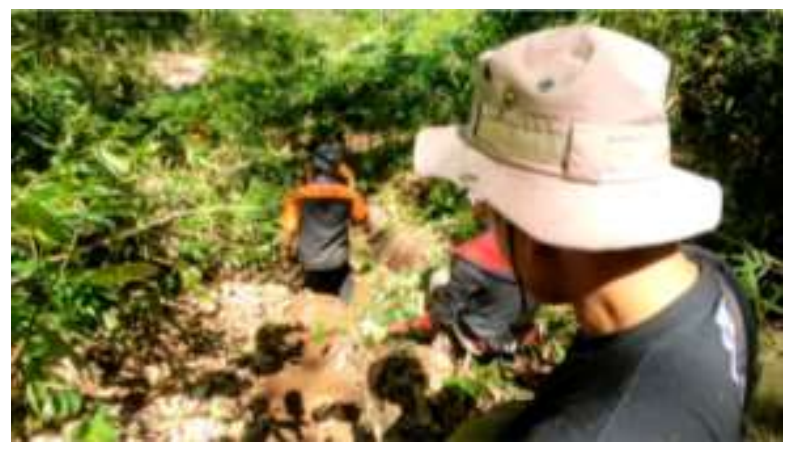

(b)

Gambar 4 (a) Rute mendaki menuju Batu Meja, (b) Rute menuruni bukit

Dari kedua gambar terlihat rute setapak menaiki dan menuruni bukit yang cukup ekstrem dan masih alami belum terjamah tangan manusia, dan berpotensi dijadikan adventure-tourism (out bond) dan juga edu-tourism.

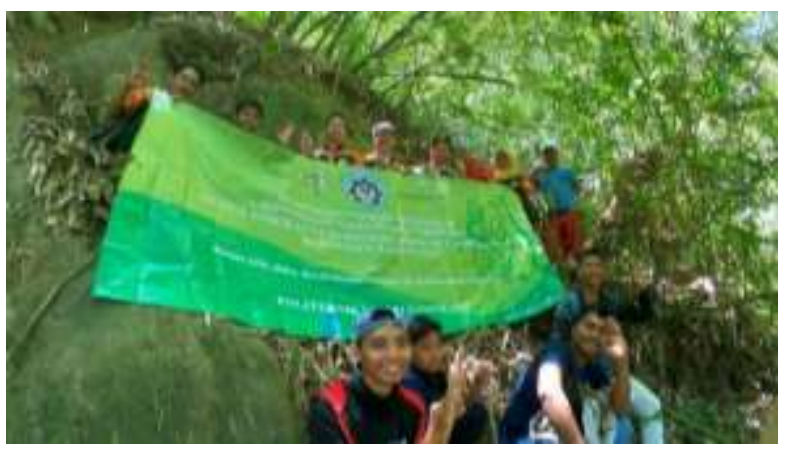

Gambar 5. Sosialisasidan Eksplorasi Sapta

Pesona Daya Tarik Batu Meja

Pembangkit Listrik Tenaga Mikro Hidro (PLTMH) adalah pembangkit listrik yang menggunakan tenaga air sebagai media utama untuk penggerak turbin dan generator. Tenaga mikrohidro, dengan skala daya yang dapat dibangkitkan 5 kilo watt hingga 50 kilo watt. Pada PLTMH proses perubahan energy kinetic berupa (kecepatan dan tekanan air), yang digunakan untuk menggerakan turbin air dan generator listrik hingga menghasilkan energi listrik. Secara teknis, mikrohidro mempunyai tiga komponen utama yaitu air sumber energi, turbin dan generator. Air yang mengalir dengan kapasitas tertentu disalurkan dengan ketinggian tertentu melalui pipa pesat menuju rumah instalasi (powerhouse). Di rumah instalasi, air tersebut akan menumbuk turbin sehingga akan menghasilkan energi mekanik berupa berputarnya poros turbin. Putaran poros turbin ini akan memutar generator sehingga dihasilkan energi listrik (Sukamta and Kusmantoro, 2013).

Kebutuhan listrik warga Dusun Lider bergantung pada Pembangkit Listrik Tenaga Mikro Hidro, memang tidak besar akan tetapi dapat memenuhi kebutuhan 2 RT dan 1 RW warga Dusun Lider, mengingat warga hidup dilingkungan tanah HGU milik perusahan swasta yang bergerak di bidang perkebunan cengkeh. Beberapa warga memiliki ide kreatif untuk membuat daya tarik wisata baru dengan memanfaatkan aliran air Listrik Tenaga Mikro Hidro menjadi pemandian anak-anak dengan dilakukan beberapa perubahanperubahan yang menarik, sehingga dapat menarik pengunjung yang hadir ke Dusun Lider.

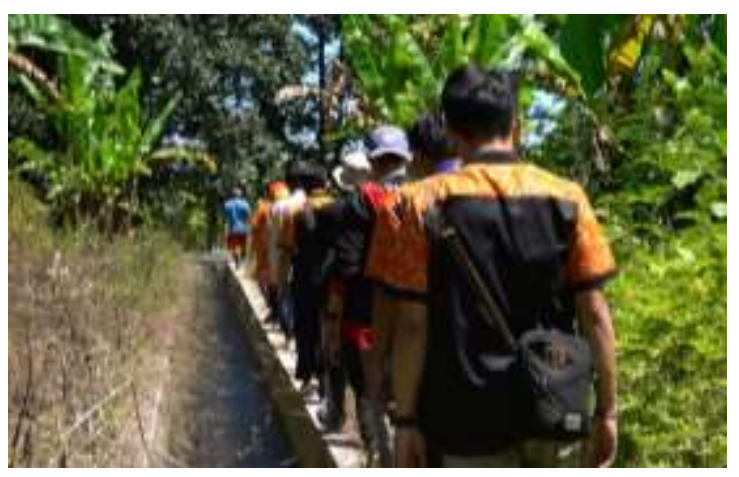

Gambar 6.Perjalanan menelusuri aliran PLTMH 


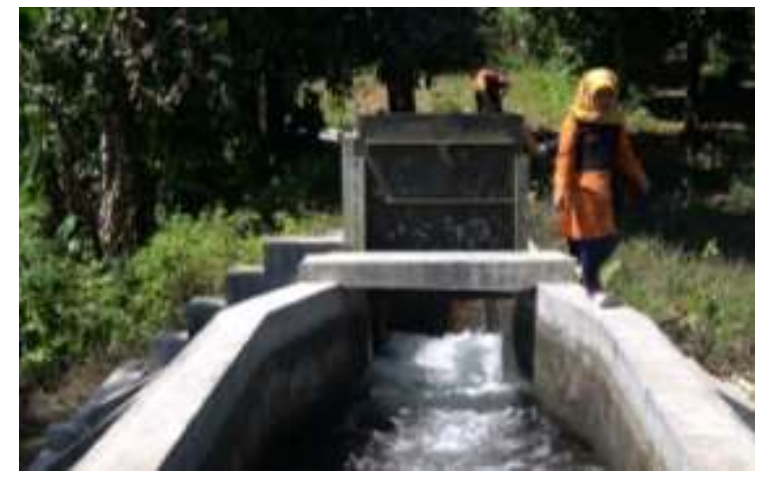

Gambar 7. Tempat pertemuan aliran air PLTMH

\section{Penutup}

\section{Simpulan}

Serangkaian kegiatan PKM yang telah dilaksanakan mulai dari observasi, survey lokasi, sosialsisai, eksplorasi hingga evaluasi, maka dapat ditarik beberapa kesimpulan sebagai berikut :

Pertama, warga dusun Lider menyambut positif dan berkeinginan tinggi untuk mengembangkan potensi wisata yang ada setelah mengikuti penerapan sosialisasi Sapta Pesona dan eksplorasi beberapa daya tarik wisata baru yang ada untuk dikembangkan.

Kedua, destinasi pariwisata dengan daya tarik utama adalah Air Terjun Lider akan dipromosikan dengan gencar oleh Program Studi Manajemen Bisnis Pariwisata Politeknik Negeri Banyuwangi melalui media sosial dan kegiatan kegiatan kepariwisataan lainnya.

Ketiga, daya tarik Batu Meja dan Pembangkit Listrik Hidro Mikro memiliki potensi besar untuk dikembangkan dan warga Dusun Lider semangat dan optimis dengan didampingi oleh tim pelaksana PKM dari Politeknik Negeri Banyuwangi.

\section{Saran}

\begin{tabular}{crr}
\multicolumn{2}{c}{ Dalam pelaksanaan sosialisasi } \\
penerapan Sapta Pesona Dalam
\end{tabular} Perencanaan Dan Pengembangan Destinasi Pariwisata Berkelanjutan Di Lider Desa Sumberarum Kecamatan Songgon Kabupaten Banyuwangi oleh Program Studi Diploma IV Manajemen Bisnis
Pariwisata Politeknik Negeri Banyuwangi. Tim pelaksana PKM sadar masih banyak kekurangan dan keberlanjutan yang perlu dilakukan dan diteruskan dalam pengabdian Dusun Lider ini, yaitu :

Pertama, perlu duduk bersama antara pengurus Kelompok Sadar Wisata (Pokdarwis) Dusun Lider, tokoh masyarakat, stakeholder pariwisata, pemerintah Desa Sumberarum dalam menyatukan visi dan komitmen untuk mengembangkan daya tarik wisata baru.

Kedua, tim pelaksana sesegera mungkin melakukan mediasi dengan pihak terkait terutama Dinas Pariwisata Kabupaten Banyuwangi dikarenakan pengembangan daya tarik wisata baru yang layak untuk dikembangkan.

Ketiga, perlu adanya koordinasi lebih lanjut dengan pihak perusahaan swasta yang memiliki wewenang terkait kepemilikan lahan, dikarenakan lokasi pengembangan daya tarik wisata baru sebagian masuk perhutani sebagain masuk tanah Hak Guna Usaha (HGU).

Keempat, perlu adanya sinergitas sehingga pentahelix pariwisata dapat berjalan bersama hingga ego sektoral dapat diminimalisir bahkan ditiadakan guna menwujudkan destinasi pariwisata yang berkelanjutan dan berdaya saing.

\section{Ucapan Terima Kasih}

Tim pelaksana PKM Program Studi Diploma IV Manajemen Bisnis Pariwisata Politeknik Negeri Banyuwangi mengucapakan terima kasih kepada Pengurus dan Anggota Kelompok Sadar Wisata (Pokdarwis) Desa Sumberarum, Kepala Dusun Lider, dan tokoh pemuda, tokoh agama, tokoh masyarakat Dusun Lider yang telah membantu berperan serta aktif mensukseskan kegiatan PKM ini.

\section{Daftar Pustaka}

Butler, R.W., 1980. The Concept of Tourism Area Cycle of Evolution: Implications for the Management of resources, XXIV. ed. Canadian 
Geographer: University of Western Ontario.

Indonesia, R., 2009. Undang-Undang RI No. 10 Tahun 2009 Tentang Kepariwisataan.

Kanom, 2015. Strategi Pengembangan Kuta Lombok Sebagai Destinasi Pariwisata Berkelanjutan. Denpasar.

Rahim, F., 2012. Pedoman Kelompok Sadar Wisata. Jakarta: Kementerian Pariwisata dan Ekonomi Kreatif.

Sukamta, S., Kusmantoro, A., 2013. Perencanaan Pembangkit Listrik Tenaga Mikro Hidro (PLTMH) Jantur Tabalas Kalimantan Timur $2,58-63$.

Sulistyani, W.A., 2018. Peran Pokdarwis dalam Penerapan Sapta Pesona Pantai Purnama Kota Dumai. 3, 111.

Sutiyono, 2019. Pesona Dusun Lider Yang Tersembunyi.

Yoety, E.A., 2006. Pengentar Ilmu Pariwisata (Edisi revisi). Bandung: Angkasa. 